\title{
Embryological Consideration of Dural AVFs in Relation to the Neural Crest and the Mesoderm
}

\author{
Michihiro Tanaka, MD, PhD \\ Department of Neurosurgery, Kameda Medical Center, Kamogawa, Japan
}

Intracranial and spinal dural arteriovenous fistulas (DAVFs) are vascular pathologies of the dural membrane with arteriovenous shunts. They are abnormal communications between arteries and veins or dural venous sinuses that sit between the two sheets of the dura mater. The dura propria faces the surface of brain, and the osteal dura faces the bone. The location of the shunt points is not distributed homogeneously on the surface of the dural membrane, but there are certain areas susceptible to DAVFs. The dura mater of the olfactory groove, falx cerebri, inferior sagittal sinus, tentorium cerebelli, and falx cerebelli, and the dura mater at the level of the spinal cord are composed only of dura propria, and these areas are derived from neural crest cells. The dura mater of the cavernous sinus, transverse sinus, sigmoid sinus, and anterior condylar confluence surrounding the hypoglossal canal are composed of both dura propria and osteal dura; this group is derived from mesoderm. Although the cause of this heterogeneity has not yet been determined, there are some specific characteristics and tendencies in terms of the embryological features. The possible reasons for the segmental susceptibility to DAVFs are summarized based on the embryology of the dura mater.

Key Words: Dural arteriovenous fistula; Neural crest; Mesoderm; Susceptibility; Embryology

\section{INTRODUCTION}

Dural arteriovenous fistulas (DAVFs) are abnormal arteriovenous shunts that develop within an epidural venous space contained between the two layers of the dura mater; they are typically vascularized by meningeal arteries. Intracranial DAVFs account for 10-15\% of all intracranial arteriovenous lesions, but no correlation has been observed between age and the frequency of aggressive neurologic symptoms. ${ }^{1-7}$
The pathoetiology of DAVFs is unknown. However, there is a higher incidence in women of involvement of a certain anatomical region on the skull base and also a higher incidence in men of involvement of a specific topographical region. ${ }^{4,8,9}$ There is a peak incidence between 30 and 50 years of age. For example, carotid cavernous DAVFs are often observed in the female population, and the shunt points of carotid cavernous DAVFs are mainly localized on the paramedian aspect of the pos-

\section{Correspondence to: Michihiro Tanaka, MD, PhD Department of Neurosurgery, Kameda Medical Center, 929 Higashi-cho, Ka- mogawa City, Chiba 296-8602, Japan Tel: +81-4-7092-2211 \\ Fax: +81-4-7099-1198 \\ E-mail: michihiro.tanaka@gmail.com}

Received: October 6, 2018

Revised: January 29, 2019

Accepted: February 15, 2019
Copyright $\odot 2019$ Korean Society of Interventional Neuroradiology This is an Open Access article distributed under the terms of the Creative Commons Attribution Non-Commercial License (http://creativecommons.org/licenses/by-nc/3.0) which permits unrestricted non-commercial use, distribution, and reproduction in any medium, provided the original work is properly cited.

pISSN 2093-9043 eISSN 2233-6273 
terior clinoid processes near the top of the clival bone. On the other hand, DAVFs located on the falx, olfactory groove, tentorium cerebelli, and lateral spinal cord are observed predominantly in the elderly male population, and this group always presents with cerebral or spinal venous hypertension and, consequently, impairment of the cerebral or spinal pial venous drainage, with aggressive clinical manifestations. ${ }^{6,8,10}$ Even if it might be a small single fistula with a low-flow shunt, the severity of symptoms and the risk of hemorrhage are high in this elderly male population. Simply because the dural membranes of the falx, olfactory groove, tentorium cerebelli, and lateral spinal cord are apart from the main dural sinuses, $100 \%$ of the shunt flow drains directly into the leptomeningeal venous system. The meninx primitiva is a sort of meningeal mesenchyme formed from mesoderm (MS) or the neural crest (NC). ${ }^{11-16}$ Since the dura mater is formed from the meninx primitiva, the difference between MS and the NC can be a clue to understanding susceptibility to DAVFs and the heterogeneity of shunt locations.

\section{MATERIAL AND METHODS}

A consecutive case series of 66 DAVFs (32 men and 34 women; mean, 68.4 years) who have been performed catheter angiography was analyzed. Selective digital subtraction angiography and high-resolution cone beam computed tomography were performed in order to identify the shunt point. The topographical area derived from NC and MS was reviewed and identified from the literatures. And the relationship between germ layers and the distribution of the shunt point was defined.

\section{ANATOMICAL CHARACTERISTICS OF DURAL MEMBRANE IN THE CENTRAL NERVOUS SYSTEM}

Dura mater means a hard mother or tough mother in Latin. This dural membrane touching the bony structures is composed of two layers. One is the dura propria, which is the internal layer of the dura mater, and the other is osteal dura, which is also called periosteal dura. $8,11,17$

Dura propria is an internal layer of the dura mater which covers the neural tissue and subarachnoid space. Dura propria is a continuous fibrous sheath formed and shaped around the brain and spinal cord, its vessels, and its nerves during embryonic development. It is evident that the morphology of the cranial dura and that of cranial bones, both originating from the initial ectomeninx, as well as the disposition of the cerebral vessels and cranial nerves, are direct consequences of the development of the brain. The embryonic development of human frontal and temporal lobes involves the formation of the anterior and middle cranial fossae with the forward displacement of the eye and the orbit. ${ }^{8,12,18}$ Another consequence in regard to the morphology of the dura mater is the formation around the brain of dural folds involving the dura propria. The falx cerebri is a dural fold formed between the bilateral cerebral hemispheres, and the tentorium cerebelli is a dural fold formed between the telencephalon, diencephalon and cerebellum (Fig. 1).

The dura mater of the falx cerebri, inferior sagittal sinus, tentorium cerebelli, and falx cerebelli and dura mater at the level of the spinal cord are composed only of dura propria which is derived from the NC cells. ${ }^{17,19,20}$ The olfactory groove is considered as the most anterior part of the falx cerebri. In fact, the dural membrane on the midline of the olfactory groove continues to the rostral part of the falx in the microscopic observation. ${ }^{21}$ These dura maters can be categorized to the NC group. Although the microstructure of dural membrane of the olfactory groove is the transitional part of the dura propria and osteal dura, crista galli is the most midline portion of the olfactory groove and it is frequently affected with the shunt of DAVF and composed mainly from dura propria. Therefore olfactory groove was defined as NC group.

The definition of superior sagittal sinus (SSS) is controversial. Because at the level of microarchitecture, the superior wall of SSS is considered as the osteal dura and the inferior

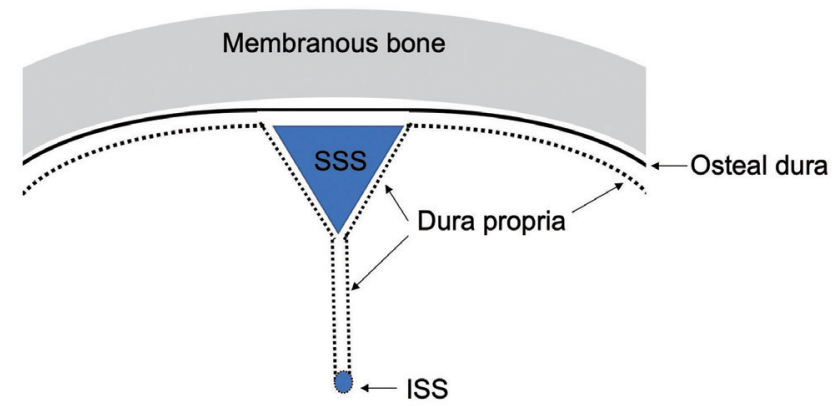

Fig. 1. The topography of dura propria and osteal dura is shown. Note that the falx cerebri, tentorium cerebelli, and spinal dura are composed only of dura propria. These structures belong to the neural crest group. SSS, superior sagittal sinus; ISS, inferior sagittal sinus. 
surface is composed from the dura propria. This particular part might be transitional part between NC and MS. According to the experimental model by Jiang et al. ${ }^{22}$ based on the transgenic mouse with a permanent NC cell lineage marker, SSS belongs to the NC origin. Therefore, SSS was categorized to the group of NC.

The topography of the NC group is characterized by the fact that they are a distance from the main dural sinuses except SSS, therefore, almost $100 \%$ of the shunt flow with DAVFs located on the NC group usually drains into the adjacent pial vein directly. Thus, the natural course of this group is usually aggressive and malignant. On the other hand, the major dural sinuses except the inferior sagittal sinus and the straight sinus are located beneath the bony structures of the skull, which means that they consist of both dura propria and osteal dura. These dura maters can be categorized as the osteal dura with dura propria group. This group corresponds to the MS because the dura mater in this group faces to the bony structure derived from the MS. The cavernous sinus, SSS, transverse sinus, sigmoid sinus, and anterior condylar confluence (ACC) at the level of the hypoglossal canal contact the surfaces of bony structures, and these dura maters belong to the MS group. The DAVFs located in the MS group are close and mostly on the surface of dural sinuses. This proximity allows the shunt flow to drain into the adjacent main dural sinuses. Therefore, the cortical venous reflux is not so significant unless there is thrombosis or a pathological steno-occlusive lesion in the affected dural sinuses. Concerning the microscopic localization of the shunt points, some of the MS group have specific shunt points, not on the surface of the dura maters, but in the bony structures. ${ }^{10,23}$ For example, the terminal feeders of the cavernous DAVFs usually run in the bony structures of the upper clivus bone that corresponds to the posterior clinoid process. The dominant feeders of ACC DAVFs are usually intraosseous arteries running in the bony structure surrounding the anterior margin of the foramen magnum. ${ }^{24}$ These terminal feeders are usually supplied from the branch of the contralateral ascending pharyngeal artery through the bony structure. Since the shunt points of the MS group are associated with endochondral bone and they often localize within the bony structure, these arteriovenous shunts should be called not dural AVFs, but transosseous or osteodural AVFs. ${ }^{23}$

Several different fistula locations have been reported in patients with ACC, hypoglossal canal or anterior condylar vein, extracranial ACC, and within the bone. Discussions about the location of fistulas have continued to this day, with a lack of detailed anatomical studies concerning osseous venous structures in this region. Although ACC is an extracranial venous structure, the shunt point is usually not exactly inside of the ACC, but in the bony structure surround the hypoglossal canal. Recent study by Mizutani et al. showed also the shunt locates within the bony structures in the case of ACC DAVFs. ${ }^{25}$

This intraforaminal space of hypoglossal canal contains both dura propria and osteal dura. The ACC DAVFs can be categorized to MS group, because the bone of this region is derived from the MS.

There are some transitional zones between the NC and MS groups. For example, the SSS, the confluence of the sinuses (torcular Herophili), and the boundary between the lateral surface of the tentorium cerebelli and the transverse sinus are defined as the borders between these two groups (Fig. 2).

\section{THE NC AS THE EMBRYOLOGICAL FACTOR RELATED TO DAVFS}

Although derived from ectoderm, the NC has sometimes been called the fourth germ layer because of its importance and pluripotency. The NCs are bilaterally paired strips of cells arising in the ectoderm at the margins of the neural tube. These cells migrate to many different locations and differ-

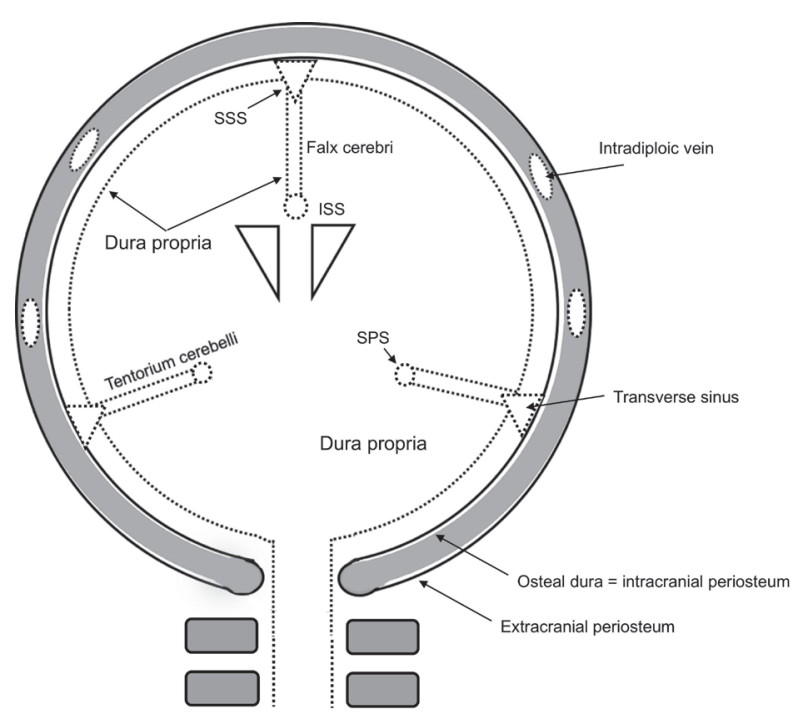

Fig. 2. The relationship between dura propria and osteal dura of the SSS. SSS, superior sagittal sinus; ISS, inferior sagittal sinus; SPS, superior petrosal sinus. 
entiate into many cell types within the embryo. ${ }^{15,26-28}$ This means that many different systems (neural, skin, teeth, head, ectomeninx, face, heart, adrenal glands, and gastrointestinal tract) will also have a contribution from NC cells. During the 4th week post-conception, mesenchyme derived from the paraxial MS and NC condenses between the developing brain and foregut to form the base of the ectomeningeal capsule. This condensation heralds the earliest evidence of skull formation. During the late-somite period, the occipital sclerotomal mesenchyme concentrates around the notochord underlying the developing hindbrain. From this region, the mesenchymal concentration extends cranially, forming a floor of the brain. ${ }^{17,29,30}$ Conversion of the ectomeninx mesenchyme into cartilage constitutes the beginning of the chondrocranium, starting at day 40 post-conception. The periosteum (osteal dura) of the frontal bones, which is of NC cell origin, contributes to the crista galli, falx cerebri, and the adjacent dura mater. Cells from the nasal septum are also derived from the NC and appear to further contribute to the falx cerebri. The anterior (rostral) prechordal region of the cranial base forms the future olfactory groove, sphenoid bone, frontal bone, and falx cerebri and is of NC origin. ${ }^{16,31-33}$

During growth and development of the neurocranium, the dura mater regulates events in the underlying brain and overlying skull by the release of soluble factors and cellular activity. Morphogenesis of the cranial bones and sutures is dependent on tissue interactions with the dura mater, which control the size and shape of bones, as well as sutural patency. ${ }^{16,34,35}$

\section{DIVERSITY IN THE CLASSIFICATIONS OF DAVFS}

Several types of classifications or grading systems have been reported in the previous literature. Djindjian and Merland $^{36}$ first described the hemodynamic patterns of DAVFs based on the findings of cerebral angiography. They already noticed that the degree of cortical venous reflux was correlated closely with the risk of hemorrhage (Table 1). Lalwani et al. ${ }^{37}$ reported that DAVFs were a hemodynamic disease that could progress at variable rates, from minimum venous restrictive disease associated with a low risk to more severe venous outflow obstruction associated with significant morbidity and death (Table 2). Cognard et al..$^{38}$ and Gomez et al. ${ }^{39}$ modified Djindjian and Merland's classification. Accord- ing to this classification, the natural course of DAVFs can be predicted, and it thus provides a clear indication for intervention (Table 3). Borden et al. ${ }^{40}$ proposed a simpler classification that focused on the flow condition of the affected sinuses and the existence of cortical venous reflux (Table 4). All these classifications were well designed from the standpoint of the hemodynamic condition of DAVFs, including the direction of the flow in the affected sinuses and the degree of cortical venous reflux. These classifications succeeded well in predicting the risk of hemorrhage and defining the indications for treatment. 7,10,39

Baltsavias et al. ${ }^{41}$ reported a revised classification of DAVFs based on a detailed analysis of the angioarchitecture using three factors: directness of venous drainage (depending on

Table1. Djindjian and Merland's classification (1978)

\begin{tabular}{ll}
\hline Type I & $\begin{array}{c}\text { Antegrade or retrograde drainage into a sinus or a } \\
\text { meningeal vein }\end{array}$ \\
Type II & $\begin{array}{c}\text { Antegrade or retrograde drainage into dural sinus } \\
\text { with cortical venous reflux }\end{array}$ \\
Type III & $\begin{array}{c}\text { Drainage solely into cortical veins } \\
\text { Type IV }\end{array}$ \\
$\begin{array}{c}\text { Drainage into one or more large venous lakes (dural } \\
\text { or subdural) that act as a mass lesion (supra- or } \\
\text { infratentorial venous lake) }\end{array}$ \\
\hline
\end{tabular}

Table 2. Lalwani's grading system for transverse-sigmoid sinus DAVFs (1993)

\begin{tabular}{ll}
\hline Grade 1 & $\begin{array}{c}\text { No venous restriction: normal antegrade venous } \\
\text { drainage without retrograde or cortical venous } \\
\text { drainage }\end{array}$ \\
Grade 2 & $\begin{array}{c}\text { Antegrade \& retrograde venous drainage with or } \\
\text { without cortical venous drainage }\end{array}$ \\
Grade 3 & $\begin{array}{l}\text { Retrograde \& cortical venous drainage without } \\
\text { antegrade venous drainage }\end{array}$ \\
Grade 4 & Cortical venous drainage only \\
\hline
\end{tabular}

DAVF, dural arteriovenous fistula.

\section{Table 3. Cognard's classification (1995)}

\begin{tabular}{|c|c|}
\hline Type I & Antegrade drainage into a sinus or meningeal vein \\
\hline Type II a & As type I but with retrograde flow into a sinus \\
\hline Type II b & Reflux into cortical veins \\
\hline Type $\|$ a+b & Reflux into both sinus and cortical veins \\
\hline Type III & $\begin{array}{l}\text { Direct cortical venous drainage without venous } \\
\text { ectasia }\end{array}$ \\
\hline Type IV & Direct cortical venous drainage with venous ectasia \\
\hline Type V & Spinal venous drainage \\
\hline
\end{tabular}

Modified Djindjian and Merland classification. 
the location of the shunt); exclusiveness of the pial venous drainage (related to venous outflow obstruction); and venous strain (as evidenced by venous congestion or venous ectasias) (Table 5). The advantage of this classification is to differentiate the dural sinus shunts or bridging vein shunts by the directness of venous drainage. This concept leads to eight different subtypes of DAVFs and may be better suited to identify which patients present with aggressive clinical symptoms, which ultimately will benefit patients by identifying those at risk.

Geibprasert et al. ${ }^{9}$ proposed a new classification based on the craniospinal epidural venous anatomy (Table 6). The craniospinal epidural spaces can be categorized into three

\section{Table 4. Borden's classification (1995)}

\begin{tabular}{cc}
\hline Type I & $\begin{array}{c}\text { Drainage directly into dural venous sinuses or } \\
\text { meningeal veins }\end{array}$ \\
Type II & $\begin{array}{c}\text { Drainage into dural sinuses or meningeal veins with } \\
\text { retrograde drainage into subarachnoid veins }\end{array}$ \\
Type III $\quad \begin{array}{c}\text { Drainage into subarachnoid veins without dural } \\
\text { sinus or meningeal venous drainage (cortical } \\
\text { venous reflux only) }\end{array}$ \\
Type IV $\quad \begin{array}{c}\text { Drainage into one or more large venous lakes (dural } \\
\text { or subdural) that act as a mass lesion (supra- or } \\
\text { infratentorial venous lake) }\end{array}$ \\
\hline
\end{tabular}

different compartments, the ventral epidural, dorsal epidural, and lateral epidural groups. Their classification is independent from the hemodynamic factors. They focused on the anatomical aspects related to their specific roles in drainage of the bone and central nervous system. This classification showed that there were close relationships between the locations of the epidural venous structures and the clinical characteristics of the disease.

Tanaka ${ }^{8}$ reported that the epidural space can be categorized into two types of domains (Table 7). One domain corresponds to the type of germ layers, that is $\mathrm{NC}$ and paraxial MS. The other domain corresponds to the type of embryological bony structures, that is endochondral bone and membranous bone. Additionally, this article showed that the dura mater of the olfactory groove, falx cerebri, tentorium cerebelli, falx cerebelli, and spinal cord consisted of only the dura propria, and this group was derived from the NC. This was one of the first articles suggesting that the type of germ layer may influence heterogeneity and the susceptibilities of the dura mater on the surface of brain and spinal cord in terms of the formation of DAVFs.

Regarding susceptibility to pathological calcification, Oyama et al. ${ }^{42}$ reported a case of ectopic ossification in the cranial dura mater in a dialysis patient with secondary hyperparathyroidism. In this case, significant calcification was

Table 5. Baltsavias's classification (2015)

\begin{tabular}{|c|c|c|c|c|c|c|c|}
\hline LVR no (benign) & $\begin{array}{c}\text { LVR yes } \\
\text { (aggressive) }\end{array}$ & $\begin{array}{c}\text { LVR } \\
\mathrm{nD} \\
\mathrm{nE} \\
\mathrm{nS}\end{array}$ & $\begin{array}{c}\text { LVR } \\
\mathrm{nD} \\
\mathrm{E} \\
\mathrm{nS}\end{array}$ & $\begin{array}{c}\text { LVR } \\
\text { D } \\
\text { E } \\
\text { nS }\end{array}$ & $\begin{array}{c}\text { LVR } \\
\mathrm{nD} \\
\mathrm{nE} \\
\mathrm{S}\end{array}$ & $\begin{array}{c}\text { LVR } \\
\text { nD } \\
\text { E } \\
S\end{array}$ & $\begin{array}{c}\text { LVR } \\
\text { D } \\
\text { E } \\
S\end{array}$ \\
\hline & BVS & & & BVS & & & BVS \\
\hline DSS & DSS & DSS & DSS & & DSS & DSS & \\
\hline EVS & EVS & EVS & EVS & & EVS & EVS & \\
\hline
\end{tabular}

Clinical aggressiveness increases from left to right.

LVR, leptomeningeal venous reflux; $n D$, non-direct; $n E$, non-exclusive; $n S$, without venous strain; $E$, exclusive; $D$, direct; $S$, with venous strain; BVS, bridging vein shunt; DSS, dural sinus shunt; EVS, emissary/epidural venous shunt.

\section{Table 6. Geibprasert and Lasjaunias's classification (2008)}

\begin{tabular}{ll}
\hline Ventral epidural group & $\begin{array}{l}\text { Osteo [cartilaginous]-epidural group that includes the basioccipital bone, the petrous pyramid, the } \\
\text { basisphenoid with its adjacent sphenoid wings, and their related dural structures. Cavernous sinus belongs } \\
\text { to this group. }\end{array}$ \\
Dorsal epidural group & $\begin{array}{r}\text { Osteo [membranous]-epidural group, which includes the superior sagittal sinus (SSS), torcular, transverse } \\
\text { sinus, medial occipital sinus, and posterior marginal sinus. }\end{array}$ \\
Lateral epidural group $\begin{array}{r}\text { Leptomeningeal-epidural group. Draining into emissary-bridging veins of the brainstem and their homologs } \\
\text { draining deep cerebral structures such as the condyloid vein at the foramen magnum, the superior petrosal } \\
\text { vein, the basal vein, the vein of Galen, the veins of the anterior cranial fossa (olfactory groove), the orbit and } \\
\text { spinal canal. }\end{array}$ \\
\hline
\end{tabular}


only noted at the tentorium cerebelli and falx cerebri, while the dura mater of the convexity was free from pathological calcification. Although the precise origin of the dural cells is obscure, they noted that dura mater develops from perineural tube mesenchymal tissue, which some NC-derived cells invade. Since NC cells are the origin of neurocranial bones, some of the cells in the dura mater have the potential to transform into osteoblast-like cells. ${ }^{12,15,30,34,43}$ Based on such case reports and several basic studies with microscopic observation using immunohistochemical techniques, the dura mater mainly consisted from the dura propria (i.e., olfactory groove, falx cerebri, inferior sagittal sinus, tentorium cerebelli, falx cerebelli, and dura mater at the level of the spinal cord) is derived from the $\mathrm{NC}^{22,44}$

The dura mater consisting of both the osteal dura and the dura propria form the cavernous sinus, SSS, transverse sinus, sigmoid sinus, and ACC (hypoglossal canal). These structures are derived from paraxial MS. These two simple anatomical domains (NC and MS groups) clearly indicate the characteristics of the DAVFs in terms of the aggressiveness of the clinical course. The concept of the embryological domains related to these two germ layers is summarized in Table 8 based on the 66 consecutive cases of DAVFs seen in our institute over the last 10 years. The mode of embolization, either a transvenous or transarterial approach, can also be defined based on these two anatomical domains. ${ }^{4,5,8,45}$ For DAVFs of the NC group, transarterial embolization is certainly indicated, simply because the NC group is separate from the main dural sinuses, and the transvenous approach is usually not indicated. Since DAVFs of the MS group are always associated with major dural sinuses, they can be primarily managed with the transvenous approach. Although there are several reports hypothesizing that DAVFs are an acquired disease associated with chronic venous hypertension or sinus

Table 7. Tanaka's classification (2016)

\begin{tabular}{|c|c|c|c|c|c|}
\hline Domains & Germ layer & Dura maters & Bony structure & Anatomical location & Clinical course \\
\hline $\begin{array}{l}\text { Ventral } \\
\text { endochondral } \\
\text { (VE) group }\end{array}$ & $\begin{array}{l}\text { Paraxial } \\
\text { mesoderm }\end{array}$ & $\begin{array}{l}\text { Osteal dura and } \\
\text { dura propria }\end{array}$ & Endochondral & $\begin{array}{l}\text { Cavernous sinus, sigmoid sinus, } \\
\text { anterior condylar confluence at } \\
\text { the level of hypoglossal canal }\end{array}$ & $\begin{array}{l}\text { Benign unless there is } \\
\text { sinus thrombosis or } \\
\text { obstruction }\end{array}$ \\
\hline $\begin{array}{l}\text { Dorsal } \\
\text { membranous } \\
\text { (DM) group }\end{array}$ & $\begin{array}{l}\text { Paraxial } \\
\text { mesoderm }\end{array}$ & $\begin{array}{l}\text { Osteal dura and } \\
\text { dura propria }\end{array}$ & Membranous & $\begin{array}{l}\text { Transverse sinus, confluence, } \\
\text { superior sagittal sinus }\end{array}$ & $\begin{array}{l}\text { Benign unless there is } \\
\text { sinus thrombosis or } \\
\text { obstruction }\end{array}$ \\
\hline $\begin{array}{l}\text { Falco-tentorial } \\
\text { spinal (FT) } \\
\text { group }\end{array}$ & Neural crest & Dura propria only & $\begin{array}{l}\text { None (apart } \\
\text { from the bony } \\
\text { structure) }\end{array}$ & $\begin{array}{l}\text { Olfactory groove, falx cerebri, falx } \\
\text { cerebelli, tentorium cerebelli, } \\
\text { spinal cord }\end{array}$ & Aggressive \\
\hline
\end{tabular}

Table 8. Summary based on the 66 consecutive cases of DAVFs shows the characteristic clinical manifestations depending on the two different germ layers

\begin{tabular}{|c|c|c|}
\hline & $\begin{array}{l}\text { Neural crest origin (consisted from dura propria } \\
\text { associated with neural crest cell) }\end{array}$ & $\begin{array}{l}\text { Paraxial mesoderm origin (consisted from } \\
\text { both periosteal dura and dura propria) }\end{array}$ \\
\hline Case (male/female) & $15(87 \% / 13 \%)$ & $51(45 \% / 55 \%)$ \\
\hline Anatomical location & $\begin{array}{l}\text { Olfactory groove, falx cerebri, falx cerebelli, inferior } \\
\text { sagittal sinus, tentorium cerebelli, lateral tentorial } \\
\text { sinus*, straight sinus, superior sagittal sinus (transitional } \\
\text { part between NC and MS), spinal cord }\end{array}$ & $\begin{array}{l}\text { Cavernous sinus, transverse sinus, sigmoid } \\
\text { sinus, anterior condylar confluence } \\
\text { (hypoglossal canal) }\end{array}$ \\
\hline Cortical venous reflux (\%) & 93 & 42 \\
\hline Clinical manifestations & $\begin{array}{l}\text { Headache, neurological deficit associated with } \\
\text { venous infarction, hemorrhage, paraplegia (central } \\
\text { myelopathy of the spinal cord) }\end{array}$ & Diplopia, chemosis, bruit, headache, tinnitus \\
\hline Mode of embolization & TAE 93\%, TAE+TVE 7\% & $\begin{array}{l}\text { TVE } 60 \%, \text { TAE 7\% } \\
\text { TAE+TVE 33\% }\end{array}$ \\
\hline
\end{tabular}

The DAVFs associated with the neural crest show aggressive clinical manifestations.

DAVF, dural arteriovenous fistulas; NC, neural crest; MS, mesodern; TAE, transaraterial embolization; TVE, transvenous embolization.

*Lateral tenrorial sinuses are the group of bridging veins which are formed by convergence of the veins draining the basal and lateral

surface of the temporal and occipital lobes. 
thrombosis, these factors may play a role, not only as an initiator, but also as a promotor to induce the DAVFs. There are several controversial points which are not yet clarified. For example, the superior petrosal sinus is the part of lateral area of the tentorium cerebelli which might be the part of the NC, however, it is also in contact with the surface on the ridge of petrosal bone that is derived from MS. The dura mater of the sphenoid wing consists from both the dura propria and the osteal dura, however the clinical behavior of the sphenoid wing DAVFs is usually aggressive because of the proximity to the deep middle cerebral vein. In this way the categorization of the superior petrosal sinus and the sphenoid wing venous structure are still unknown and they might have two aspects of both the NC and the MS.

\section{SUMMARY}

From the standpoint of germ layers, there are only two types of domains in the dura mater. One is the dura mater from the NC, and the other is from paraxial MS. The DAVFs associated with the NC present with a higher incidence of significant venous reflux into the leptomeningeal venous system with malignant clinical manifestations in the elderly male population. The DAVFs on the surface of the dura mater derived from MS show less incidence of cortical venous reflux, with a relatively benign clinical course and female predominance. ${ }^{2}$ The domains of dura mater based on the germ layers may affect their susceptibilities to the formation of DAVFs. The concept of the germ layers might be one of the clues to clarify the pathoetiology of DAVFs.

\section{Acknowledgments}

The author is grateful to Prof. Dae Chul Suh for suggesting the topic of this article.

\section{REFERENCES}

1. Lasjaunias P, Chiu M, Ter Brugge K, Tolia A, Hurth M, Bernstein M. Neurological manifestations of intracranial dural arteriovenous malformations. J Neurosurg 1986;64:724-730

2. Miller TR, Gandhi D. Intracranial dural arteriovenous fistulae: clinical presentation and management strategies. Stroke 2015:46:2017-2025

3. Söderman M, Pavic L, Edner G, Holmin S, Andersson T. Natural history of dural arteriovenous shunts. Stroke 2008;39:1735-1739

4. Baltsavias G, Valavanis A. Endovascular treatment of 170 consecutive cranial dural arteriovenous fistulae: results and complications. Neurosurg Rev 2014;37:63-71

5. Zhao J, Xu F, Ren J, Manjila S, Bambakidis NC. Dural arteriovenous fistulas at the craniocervical junction: a systematic review. J Neurointerv Surg 2016;8:648-653

6. Gross BA, Du R. The natural history of cerebral dural arteriovenous fistulae. Neurosurgery 2012;71:594-602; discussion 602-603

7. Gandhi D, Chen J, Pearl M, Huang J, Gemmete JJ, Kathuria S. Intracranial dural arteriovenous fistulas: classification, imaging findings, and treatment. AJNR Am J Neuroradiol 2012;33:10071013

8. Tanaka M. Embryological consideration of dural AVF. Acta Neurochir Supp/ 2016;123:169-176

9. Geibprasert S, Pereira V, Krings T, Jiarakongmun P, Toulgoat F, Pongpech S, et al. Dural arteriovenous shunts: a new classification of craniospinal epidural venous anatomical bases and clinical correlations. Stroke 2008;39:2783-2794

10. Gupta A, Periakaruppan A. Intracranial dural arteriovenous fistulas: a review. Indian J Radiol Imaging 2009;19:43-48

11. MacK J, Squier W, Eastman JT. Anatomy and development of the meninges: implications for subdural collections and CSF circulation. Pediatr Radio/ 2009;39:200-210

12. Adeeb N, Mortazavi MM, Tubbs RS, Cohen-Gadol AA. The cranial dura mater: a review of its history, embryology, and anatomy. Childs Nerv Syst 2012;28:827-837

13. Aurboonyawat T, Pereira V, Krings T, Toulgoat F, Chiewvit P, Lasjaunias P. Patterns of the cranial venous system from the comparative anatomy invertebrates. Part III. The ventricular system and comparative anatomy of the venous outlet of spinal cord and its homology with the five brain vesicles. Interv Neuroradiol 2008;14:125-136

14. O'Rahilly R, Müller F. The development of the neural crest in the human. J Anat 2007;211:335-351

15. Morriss-Kay G, Ruberte E, Fukiishi Y. Mammalian neural crest and neural crest derivatives. Ann Anat 1993;175:501-507

16. Osumi-Yamashita N, Eto K. Mammalian Cranial Neural Crest Cells and Facial Development: (cranial neural crest cells/facial development/mammal/retinoic acid receptor/gene expression). Develop Growth \& Differ 1990;32:451-459

17. O'Rahilly R, Müller F. The meninges in human development. J Neuropathol Exp Neurol 1986;45:588-608

18. Tubbs RS, Loukas M, Louis RG Jr, Shoja MM, Acakpo-Satchivi L, Blount JP, et al. Anatomy of the falcine venous plexus. J Neurosurg 2007;107:155-157 
19. Wiltse LL. Anatomy of the extradural compartments of the lumbar spinal canal. Peridural membrane and circumneural sheath. Radiol Clin North Am 2000;38:1177-1206

20. Nicholas DS, Weller RO. The fine anatomy of the human spinal meninges. A light and scanning electron microscopy study. J Neurosurg 1988;69:276-282

21. Lang J. Anterior cranial fossa, the approach to the orbit and the ethmoid bone. In: Clinical Anatomy of the Head. Berlin: Springer Berlin Heidelberg, 1981;67-93

22. Jiang $X$, Iseki S, Maxson RE, Sucov HM, Morriss-Kay GM. Tissue origins and interactions in the mammalian skull vault. Dev Biol 2002;241:106-116

23. Berenstein A, Lasjaunias P, ter Brugge KG. Dural Arteriovenous Shunts. In: Surgical Neuroangiography. Berlin: Springer Berlin Heidelberg 2004;565-607

24. Spittau B, Millán DS, El-Sherifi S, Hader C, Singh TP, Motschall E, et al. Dural arteriovenous fistulas of the hypoglossal canal: systematic review on imaging anatomy, clinical findings, and endovascular management. J Neurosurg 2015;122:883-903

25. Mizutani K, Akiyama T, Minami Y, Toda M, Fujiwara H, Jinzaki M, et al. Intraosseous venous structures adjacent to the jugular tubercle associated with an anterior condylar dural arteriovenous fistula. Neuroradiology 2018;60:487-496

26. Le Douarin NM, Dupin E. The Neural Crest, a Fourth Germ Layer of the Vertebrate Embryo. In: Trainor PABT-NCC. Neural Crest Cells. Boston: Elsevier, 2014;3-26

27. Calloni GW, Le Douarin NM, Dupin E. High frequency of cephalic neural crest cells shows coexistence of neurogenic, melanogenic, and osteogenic differentiation capacities. Proc Natl Acad SciU S A 2009;106:8947-8952

28. Hirasawa T, Kuratani S. Evolution of the vertebrate skeleton: morphology, embryology, and development. Zoological Lett 2015;1:2

29. Noden DM, Schneider RA. Neural crest cells and the community of plan for craniofacial development: historical debates and current perspectives. Adv Exp Med Biol 2006;589:1-23

30. Gagan JR, Tholpady SS, Ogle RC. Cellular dynamics and tissue interactions of the dura mater during head development. Birth Defects Res CEmbryo Today 2007;81:297-304

31. Wilde JJ, Petersen JR, Niswander L. Genetic, epigenetic, and environmental contributions to neural tube closure. Annu Rev Genet 2014:48:583-611

32. Katoh H, Shibata S, Fukuda K, Sato M, Satoh E, Nagoshi N, et al.
The dual origin of the peripheral olfactory system: placode and neural crest. Mol Brain 2011;4:34

33. Quackenbush KE, Luna-Fineman S, Magee JF, Gundogan M, Golobi M, Irie T, et al. Neuroblastoma involvement of the falx cerebri. Pediatr Blood Cancer 2009;53:1337-1339

34. Doro D, Liu A, Grigoriadis AE, Liu KJ. The osteogenic potential of the neural crest lineage may contribute to craniosynostosis. Mol Syndromol 2019;10:48-57

35. Rodionov AA, Asfandiyarov RI. Morphogenesis of the epidural space in humans during the embryonic and early fetal periods. Neurosci Behav Physiol 2010;40:137-142

36. Djindjian R, Merland JJ. Super-Selective Arteriography of the External Carotid Artery. Berlin: Springer Berlin Heidelberg, 1978

37. Lalwani AK, Dowd CF, Halbach V V. Grading venous restrictive disease in patients with dural arteriovenous fistulas of the transverse/sigmoid sinus. J Neurosurg 1993;79:11-15

38. Cognard C, Gobin YP, Pierot L, Bailly AL, Houdart E, Casasco A, et al. Cerebral dural arteriovenous fistulas: clinical and angiographic correlation with a revised classification of venous drainage. Radiology 1995;194:671-680

39. Gomez J, Amin AG, Gregg L, Gailloud P. Classification schemes of cranial dural arteriovenous fistulas. Neurosurg Clin N Am 2012;23:55-62

40. Borden JA, Wu JK, Shucart WA. A proposed classification for spinal and cranial dural arteriovenous fistulous malformations and implications for treatment. J Neurosurg 1995;82:166-179

41. Baltsavias G, Roth P, Valavanis A. Cranial dural arteriovenous shunts. Part 3. Classification based on the leptomeningeal venous drainage. Neurosurg Rev 2015;38:273-281

42. Oyama Y, Kazama JJ, Fukagawa M, Arakawa Y, Ezuka I. Ectopic ossification in the cranial dura mater in dialysis patients with secondary hyperparathyroidism. NDT Plus 2010;3:64-67

43. Kuratani S. Craniofacial development and the evolution of the vertebrates: the old problems on a new background. Zoolog Sci 2005;22:1-19

44. Noden DM, Trainor PA. Relations and interactions between cranial mesoderm and neural crest populations. J Anat 2005;207:575601

45. Lekkhong E, Pongpech S, Ter Brugge K, Jiarakongmun P, Willinsky R, Geibprasert S, et al. Transvenous embolization of intracranial dural arteriovenous shunts through occluded venous segments: experience in 51 patients. AJNR Am J Neuroradiol 2011;32:1738-1744 